\title{
Origin of certain eponyms used in pediatrics derived from literature
}

\author{
Alejandro Donoso F., M.D. ${ }^{a}$ and Daniela Arriagada S., M.D. ${ }^{a}$
}

\begin{abstract}
Eponyms are commonly used in medicine; some of them derive from the name of literary characters or make reference to classical myths. In this article, we underline some eponyms obtained from literature and review the characteristics of the literary characters, the circumstances that led to their creation, and the physicians who coined and adapted them to the field of medicine. A literary eponym offers a cultural and humanist perspective to our daily practice and is part of the history of medicine.

Key words: humanities, literature, eponyms, syndrome.
\end{abstract}

http: / / dx.doi.org/10.5546/ aap.2019.eng.188

To cite: Donoso FA, Arriagada SD. Origin of certain eponyms used in pediatrics derived from literature. Arch Argent Pediatr 2019;117(3):188-194.

\section{INTRODUCTION}

The name of clinical signs, diseases, and syndromes may be related to a description (strawberry tongue, Harlequin sign), the physician who first described them (Kawasaki disease), the causative alteration (glucose-6-phosphate dehydrogenase deficiency) or the underlying pathological process (acute renal failure). ${ }^{1}$ However, some have taken their name from ancient literature or

a. Unit of Pediatric Critical Patients, Hospital Clínico Metropolitano La Florida, Santiago, Chile.

E-mail address:

Alejandro Donoso F., M.D.: adonosofuentes@gmail. com

Funding:

None.

Conflict of interest:

None.

Received: 7-4-2018

Accepted: 9-24-2018

\section{RAPUNZEL SYNDROME ${ }^{2}$}

Rapunzel, the main character of the tale written by the Grimm brothers, Jacob and Wilhelm, was the "the most beautiful child beneath the sun." Her most delightful characteristic was her long, golden hair, "as fine as gold thread and as strong as a dandelion." When Rapunzel was 12 years old, Gothel, a sorcerer, locked her up in a tower with neither stairs nor a door, just a tiny room with only one small window at the top. Whenever she wanted to go inside, she would stand beneath the tower and called out: "Rapunzel, Rapunzel, let down your hair." In the same manner, this allowed her beau to visit her (Figure 1).

Jacob (1785-1863) and his brother Wilhelm (1786-1859) were born in Hanau, Hesse. They were the elder children of a German bourgeois family. In 1796, their father died and they were forced to migrate to Kassel. A period of economic hardship struck and so they were left out of the social life of that time, which led them to focus obsessively on their studies at the Law School of the University of Marburg. ${ }^{3}$

When Prussia was invaded by Napoleon's army in 1806, the new government sought to suppress the local culture of the old regime. The Brothers Grimm considered themselves patriotic folklorists so, at that time, their writings took a turn to reinforce their national-populist strain. Thus, they decided to compile the stories, myths, and legends of the popular oral tradition of Germany with maximum respect for their simplicity. This was finally reflected in Kinder-und Hausmärchen (The Children's and Household Tales), ${ }^{4}$ which were published in two volumes, in 1812 and 1815 . These are popularly 
known as The Grimms' Fairy Tales although they were not created by them. In the beginning, they were not much sold in Germany because the stories had plenty of footnotes and did not include illustrations; besides, the brothers considered that they were not aimed at the child audience. In spite of this, when Goethe read their work, in his letters to Charlotte von Stein, he pointed out that it was destined to "make children happy." This way, once the Brothers Grimm discovered their new child audience, they proceeded to tone down their stories. The last edition supervised by them was launched in 1857. The first translation into Spanish was done in 1879.

More than 200 tales in their collection make up an anthology of fairies, farces, fables, and allegories. In 2005, the Grimms' Fairy Tales were listed by the United Nations Educational, Scientific and Cultural Organization (UNESCO) in its Memory of the World Program. ${ }^{5}$

The Brothers Grimm's work was not only limited to compiling stories, they also carried out linguistic research and taught at the universities of Kassel, Göttingen, and Humboldt. In the last years of their lives, they focused on developing the largest and most comprehensive dictionary of the German language, of which they were able to publish just the first volume. At present, the Brothers Grimm are recognized as the founders of Germanic philology.

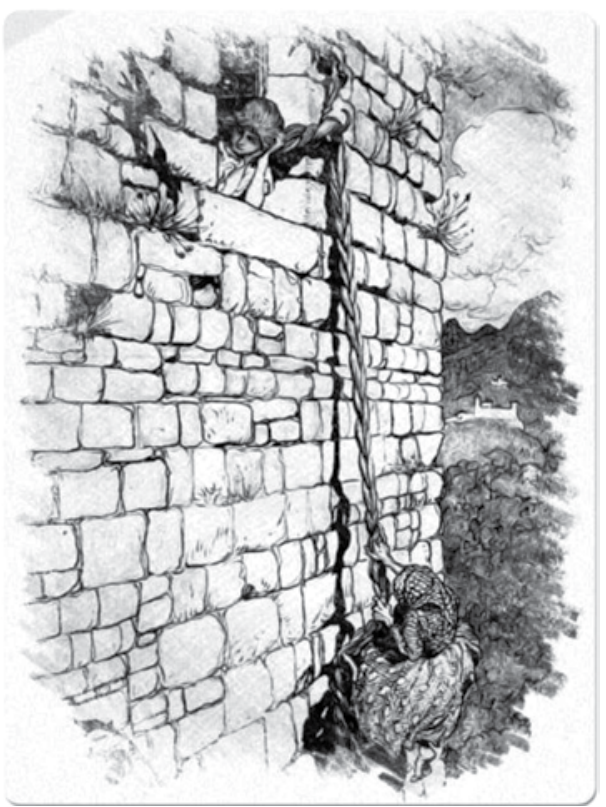

Arthur Rackham (1909)
Over a century and a half later, Vaughan et al. ${ }^{6}$ described two cases of gastric trichobezoar that extended to the ileocecal valve. The ball of twisted hair was firmly adhered to the intestinal wall and was highly resistant to traction, thus causing multiple perforations. They coined the name Rapunzel syndrome for this infrequent form of gastric trichobezoar which extended to the small intestine or ascending colon, usually observed in girls and young women with underlying psychiatric disorders. ${ }^{7-10}$

\section{MÜNCHHAUSEN'S SYNDROME 11}

Karl Friedrich Hieronymus, Baron of Münchhausen (1720-1797), was a German cavalry officer who enlisted in the Russian army and participated in the military campaigns against the Ottoman Empire until his 30s. When he returned home to Bodenwerder, he told extravagant, amazing, and fantastic stories about his adventures.

Based on his deeds, which included flying over the battlefield sitting on a cannonball (Figure 2), traveling to the moon or to hell, dancing inside the stomach of a whale, among others, German scientist and writer Rudolf Erich Raspe (17371794) created a fanciful literary character called "Baron Münchhausen," which first appeared in the book titled Baron Münchhausen's Narrative of

\section{FIGURE 2. Baron Münchhausen}

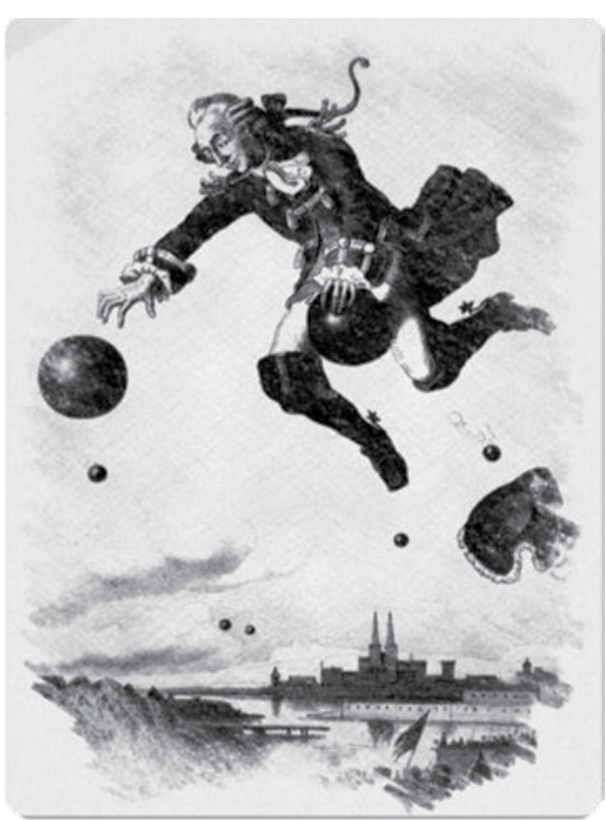

Baron Münchhausen rides a cannonball. August von Wille (before 1872) 
his Marvellous Travels and Campaigns in Russia, published in English, in London in 1785. Such unexpected international fame of deceiver and liar caused an irreparable damage to the authentic baron's reputation, which deeply affected him.

In 1786, the poet Gottfried August Bürger translated the stories into German and even expanded them. The author of the original book remained anonymous until 1847, when Bürger's biography was published. This would explain why no legal actions were pursued by the baron to regain his honor.

This term was coined by Sir Richard Asher ${ }^{12}$ in 1951 to characterize the individuals who intentionally showed signs and symptoms that generated numerous hospital visits and admissions. Originally, he classified them into three categories: abdominal, hemorrhagic, and neurological. Two decades after, English physician Samuel Meadow ${ }^{13}$ described two children with signs and symptoms induced or manufactured by their mothers and called this Münchhausen's syndrome by proxy. At present, this term is still used in pediatrics, although there are few studies on the epidemiology, treatment, and prognosis of Münchhausen's syndrome because most cases correspond to reports. ${ }^{14}$

\section{PICKWICKIAN SYNDROME}

Fat Joe is a popular character in The Posthumous Papers of the Pickwick $\mathrm{Club}^{15}$ (also known as The Pickwick Papers), a novel issued in installments in 1836 by young English journalist Charles Dickens (1812-1870) under the pseudonym of Boz. This elegant, satirical, and humorous novel tells the

\section{Figure 3. Fat Joe}

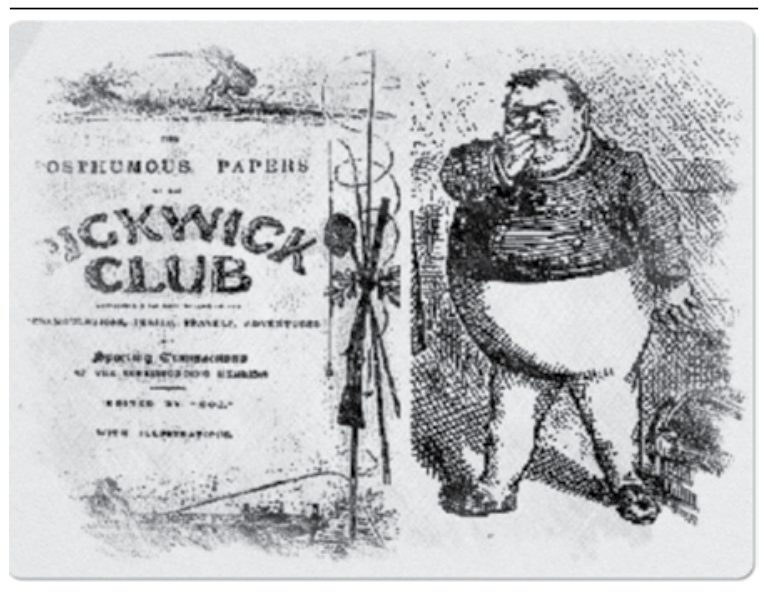

To the left, the cover of The Posthumous Papers of the Pickwick Club (1836). To the right, Joe, the fat boy. adventures of Mr. Samuel Pickwick and his extravagant friends during their journey through England guided by their philanthropic desire; the novel depicted the habits of the nineteenthcentury English society.

Dickens' childhood was marked by poverty and his wanderings through the streets of London. This experience probably made him empathize with abandoned children and poor, destitute, and disabled people. He learned stenography and worked as a journalist at the Parliament and later earned his living writing. ${ }^{16}$

Dickens played a relevant role in medicine ${ }^{17}$ by describing characters with different conditions. He also promoted the treatment of children and, more notably, revealed the human side of poverty and disability.

Dickens also participated in the preservation of the first children's hospital in the British Empire ${ }^{18}$ by publicizing it and raised funds by reading $A$ Christmas Carol.

Dickens was a keen observer who made marvelous descriptions of his characters and provided many of the characteristics of sleep disorders ${ }^{19}$ more than a century before medical science recognized them as such. ${ }^{20}$ Fat Joe, Mr. Wardler's servant, was described to have frequent unconquerable sleep episodes and as hard to wake up. In addition to his obesity (over $125 \mathrm{~kg}$ ), he had a red face (polycythemia?) and snored loudly (Figure 3).

Many years later, a group of Boston hospitalists suggested the term Pickwickian syndrome $^{21}$ to describe a patient who had sought treatment after his symptoms made him sleep during a poker hand, even though he had excellent cards. However, by the end of the $19^{\text {th }}$ century, the condition of a patient was described as similar to that of Dickens' character. ${ }^{22}$ Later, Sir William Osler mentioned the "fat boy" in his book to discuss somnolence and obesity. ${ }^{23}$

However, there are some discrepancies between the history and the use of this eponym because Mr. Pickwick did not suffer obesityassociated somnolence. In addition, the term proposed by Burwell (Pickwickian syndrome) also seemed wrong because Joe was never a member of the Pickwick Club. ${ }^{24}$ Finally, it has been pointed out that Dickens was not the first one to make this clinical description. ${ }^{24,25}$

The first reports in children date from the middle of the last century. ${ }^{26,27}$ At present, it is known as obesity hypoventilation syndrome (OHS). ${ }^{28-30}$ 


\section{ALICE IN WONDERLAND SYNDROME}

The name of this syndrome refers to the character in Lewis Carroll's 1865 Alice's Adventures in Wonderland. ${ }^{31}$ In the novel, Alice suffers alterations of perception and feels that her body enlarges or that some parts change in shape, size or in relation to the rest of her body.

Charles Lutwidge Dodgson (1832-1898), better known by his pen name Lewis Carroll, was a writer, photographer, mathematician, and deacon of the Anglican Church.

According to his diary, it all started in July $4^{\text {th }}, 1862$ during his boat trips down the River Thames with the Liddell sisters -Lorina, Alice, and Edith-, the daughters of Henry Liddell, vice chancellor of Oxford University and dean of Christ Church College, where Dodgson was a Mathematics professor. ${ }^{32}$ At the request of Alice, he made up the argument of his famous novel, just to entertain the girls. Alice was impressed with the story and asked him to write it down. Once he completed the manuscript, Carroll gave it to her as a Christmas present, including his own illustrations (initially, it was called Alice's Adventures Under Ground). The book was finally published in 1865 with the title we know today and the illustrations of John Tenniel. The controversy in relation to Alice's role as inspiration for the book persists even today.

FIgURE 4. Alice in Wonderland

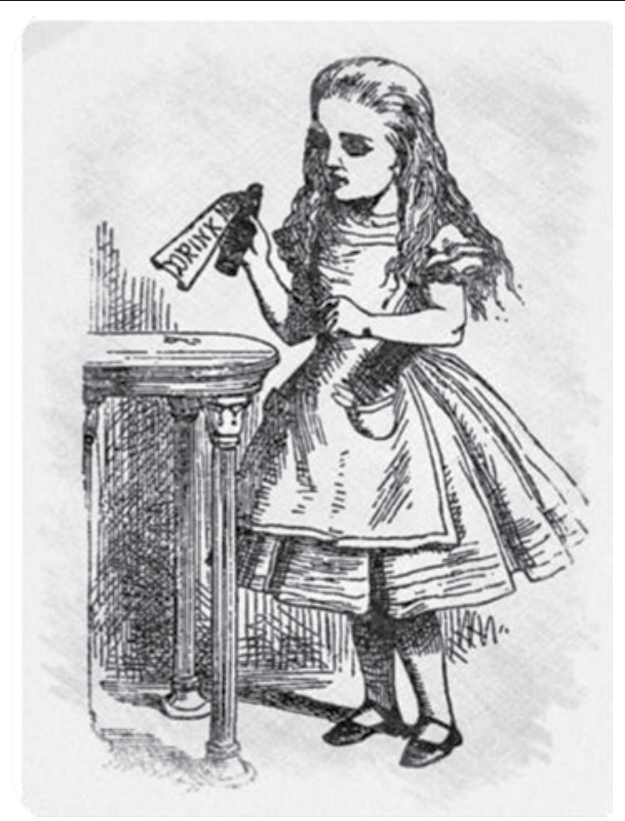

Alice's Adventures in Wonderland

Illustration by John Tenniel (1865)
As it is known, the girl followed a white rabbit into a strange world, where she drank from a bottle labeled "drink me" and shrank (Figure 4). Then her body enlarged when she ate a cake labeled "eat me," with her head even touching the ceiling. Later her trunk contracted when she ate the mushroom the blue caterpillar gave her. In addition, Alice's inability to express her symptoms was manifested when she said: "Being so many sizes in one day is confusing. Quite confusing indeed."

This neurological syndrome affects the human senses of vision, hearing, and touch, as well as the perception of time. It is characterized by depersonalization, distorted perception of body image (micro- and macrosomatognosia) and visual alterations (micropsia, macropsia, teleopsia, metamorphosia, etc.), among other complex symptoms. ${ }^{33,34}$

In 1955, British psychiatrist John Todd described illusory distortions of body image in his patients. ${ }^{35}$ Although in scientific literature this is known as depersonalization/derealization syndrome, Todd observed the similarity with Alice's peculiar experience in the novel and renamed this entity. Three years before, Caro Lippman ${ }^{36}$ had described seven patients with migraines and unusual body image distortions and noted similarities with Alice's adventures; besides, he pointed out that Lewis Carroll himself had migraines associated with some visual alterations, which probably inspired him.

It had been mainly described in children ${ }^{32}$ who had epilepsy, ${ }^{37}$ Epstein-Barr encephalitis, ${ }^{38}$ and in relation to drug use. ${ }^{39}$

\section{ONDINE'S CURSE}

Congenital central hypoventilation syndrome is informally known with the eponym "Ondine's curse." This strange entity is characterized by the loss of automatic control during sleep, in the absence of a primary disease, and has been recently attributed to a mutation in the PHOXB2 gene. ${ }^{40}$ This syndrome was first described by Robert Mellins et al. in 1970. ${ }^{41}$

Much controversy has emerged regarding the creation of this eponym. Different origins and characteristics of alleged wickedness have been attributed to Ondine, the water nymph in love. The first physicians who used the term were Severinghaus and Mitchell in 1962, during a meeting of the Western Society for Clinical Research, where three neurosurgical patients were presented. ${ }^{42}$ The explanation given by the 
authors to choose the name "Ondine's curse" was rather inaccurate. ${ }^{43}$

In 1939, French writer Jean Giraudoux (18821944) adapted for the stage the novel Undine, by German novelist Friedrich Heinrich Karl de la Motte, Baron Fouqué, which had been published in 1811. Giraudoux's "Ondine" voluntarily decided to abandon her husband after finding out about his infidelity while, at the same time and to avoid getting punished, he proclaimed that she had cheated on him first. Thus, absorbed in the romantic plot, it is observed that the gentleman in love told Ondine that his life had turned tempestuous without her: "Un moment d'inattention, et j'oublieraid'entendre, de respirer... Il est mort parce que respirer l'embêtait, dirat-on... Il est mort d' amour" ("A single moment of inattention, and I forget to breathe... He died, they will say, because it was a nuisance to breathe... He died of love.") (Figure 5). This is the story that gives origin to the eponym of interest here.

As mentioned, Ondine had never placed a curse and her husband's death was the result of his adultery; besides, she never presented this syndrome because she did not show an alteration in her breathing pattern. ${ }^{44,45}$

Given the existing confusion about this eponym, in both the literary and the medical

\section{FIGURE 5. Ondine}

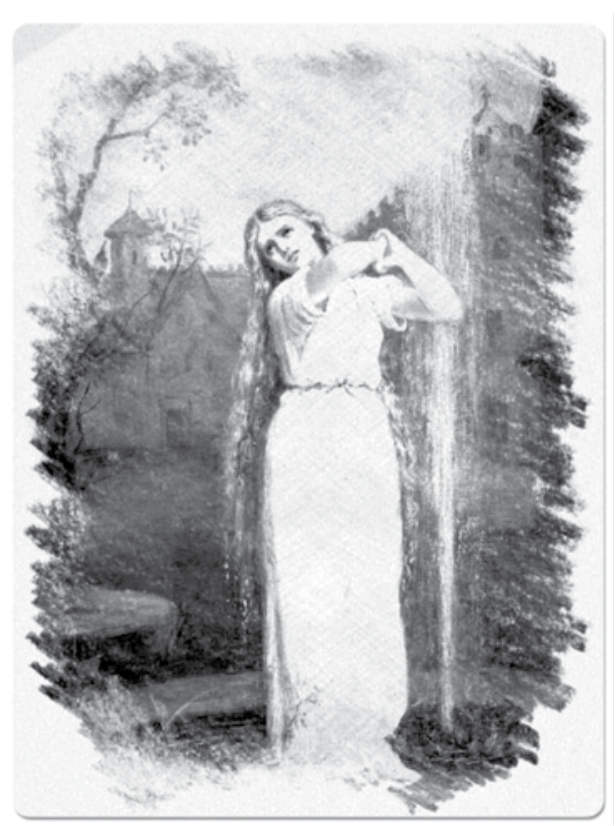

John William Waterhouse (1872) fields, many authors have proposed to discontinue its use and change it for a more descriptive term.

\section{DISCUSSION}

The use of eponyms is frequent in medical language and has persisted to date, ${ }^{1,46}$ however, there is a valid discussion on whether their use is advisable. ${ }^{47,48}$ In our opinion, eponyms generate an interest in the history of medicine, deepen our knowledge, and enrich medical language, therefore making our daily practice more human.

Literary eponyms are illustrative paradigms of the mutual and widely renowned influence that takes place in the scientific and social disciplines. In this manner, medicine and literature are closely related to each other. This may be noted in the disease, pain, and death themes present in great works of literature (Dante, Cervantes, Moliere, Shakespeare, Mann, among others), in the role of literature in comprehensive medical training (medical ethics), and, lastly, in the number of great writers who were also physicians (Chekhov, Bulgakov, Rabelais, Conan Doyle, among many others). A less studied aspect is the impact of literary characters on our scientific language.

In this review, we have observed that, in some cases, the characteristics of the main character are similar to those of the medical entity (Pickwickian syndrome, Alice in Wonderland syndrome) while in others, names were selected as metaphors (Rapunzel, Münchhausen). In addition, several literary sources that lent their name or that of their characters were written approximately a century before the initial description of the medical condition, once they had become a wellsettled component in social culture.

Literary material, like any other material resulting from art, and especially works of art of universal renown, are of great value in medicine due to the effect artistic symbolic images have on the stimulation of imagination and abductive reasoning, which are key mental functions for the development of diagnostic (patient treatment) and scientific hypotheses (medical research). ${ }^{49,50}$

The current trend in medicine favors the use of accurate, direct scientific descriptions to refer to medical conditions instead of metaphorical eponyms. Although it is understandable, it is believed that besides helping to improve physicians' culture, eponyms also offer warmth, brightness, and familiarity, all of which are highly necessary in our daily practice. 


\section{REFERENCES}

1. Zafra Anta MA, MedinoMuñoz J, GorrotxategiGorrotxategi P,PonteHernandoF.Usodeepónimosenrevistas pediátricas en español en los últimos 10 años. ¿Estácambiando? An Pediatr (Barc). 2018; 88(1):58-60.

2. Naik S, Gupta V, Naik S, Rangole A, et al. Rapunzel syndrome reviewed and redefined. Dig Surg. 2007; 24(3):157-61.

3. Denecke L. Brothers Grimm: German folklorists and linguists. [Accessed on: March 29 ${ }^{\text {th }}, 2018$ ]. Available at: https: / / www.britannica.com/biography / BrothersGrimm.

4. Encyclopedia of World Biography. Brothers Grimm Biography. [Accessed on:April 1 ${ }^{\text {th }}$,2018]. Availableat:http:/ / www.notablebiographies.com/Gi-He/Grimm-Brothers. html.

5. Organización de las Naciones Unidas para la Educación, la Ciencia y la Cultura. Veintinueve obras y colecciones documentales inscritas en el Registro "Memoria del Mundo". [Accessed on: April 10 ${ }^{\text {th }}$, 2018]. http://portal. unesco.org/es/ev.php-URL_ID=28029\&URL_DO=DO_ TOPIC\&URL_SECTION=201.html.

6. Vaughan EDJr,SawyersJL,H.W.ScottHWJr. The Rapunzel syndrome-an unusual complication of intestinal bezoar. Surgery. 1968; 63(2):339-43.

7. Rabie ME, Arishi AR, Khan A, Ageely H, et al. Rapunzel syndrome: The unsuspected culprit. World J Gastroenterol. 2008; 14(7):1141-3.

8. Sharma AK, Hussain A, Walia D, Bansal S. Trichobezoar and Rapunzel syndrome: A review. Onc Gas Hep Rep. 2015;4:28-9.

9. Anzieta VJ, Felmer EO, Gabrielli NM, Venturelli F, et al. Obstrucción Intestinal causada por Tricobezoar: síndrome de Rapunzel. RevMedChil. 2008;136(8):1027-30.

10. Bargas Ochoa M, Xacur Hernández M, Espadas Torres M, Quintana Gamboa A, et al. Síndrome de Rapunzel con doble tricobezoar simultáneo en una adolescente: Reporte de caso. Rev Chil Pediatr. 2018; 89(1):98-102.

11. O'shea B, McGennis A, Cahill M, Falvev J. Munchausen's syndrome. Br J Hosp Med. 1984; 31(4):269-74.

12. AsherR. Munchausen's syndrome.Lancet. 1951;1(6650):33941.

13. Meadow R. Munchausen syndrome by proxy. The hinterland of child abuse. Lancet. 1977; 2(8033):343-5.

14. Sousa D Filho, Kanomata EY, Feldman RJ, Neto AM. Munchausen syndrome and Munchausen syndrome by proxy: a narrative review. Einstein (Sao Paulo). 2017;15(4):51621.

15. Dickens C. The posthumous papers of the Pickwick Club. London: Chapman and Hall; 1836.

16. Edwards M. Reflections on Charles Dickens. London J Prim Care (Abingdon). 2012; 5(1):49-50.

17. Charles Dickens (obituary). Br Med J. 1870; 2(519):636.

18. Markel H. Charles Dickens' work to help establish Great Ormond Street Hospital, London. Lancet. 1999; 354(9179):673-5.

19. Kryger M. Charles Dickens: impact on medicine and society. J Clin Sleep Med. 2012; 8(3):333-8.

20. Burwell CS, Robin ED, Whaley RD, Bickelmann AG. Extreme obesity associated with alveolar hypoventilation-a Pickwickian Syndrome. 1956. Obes Res. 1994; 2(4):390-7.

21. Bickelmann AG, Burwell CS, Robin ED, Whaley RD. Extreme obesity associated with alveolar hypoventilation; a Pickwickian syndrome. Am J Med. 1956; 21(5):811-8.

22. Caton R. Case of narcolepsy. Clin Soc Trans. 1889; 22:133-7.
23. Osler W.Principles and Practice of Medicine. $6^{\text {th }}$ ed. London: Sidney Appleton; 1905.

24. Navarro FA. Dos personajes literarios en el lenguaje de la neurología: Pickwick (1). Rev Neurol. 1997; 25(144):1297302.

25. Kryger MH. Sleep apnea. From the needles of Dionysius to continuous positive airway pressure. Arch Intern Med. 1983; 143(12):2301-3.

26. Spier N, Karelitz S. The Pickwickian syndrome: case in a child. AMA J Dis Child. 1960; 99:822-7.

27. Cayler GG, Mays J, Riley HD Jr. Cardiorespiratory syndrome of obesity (Pickwickian syndrome) in children. Pediatrics. 1961; 27:237-45.

28. Branstiter GW, Lempert NL, Sotomayor T, Crombet O, et al. Obesity hypoventilation syndrome in a 12-year-old child requiring therapeutic phlebotomy: case report and review of the literature. Pediatr Int. 2014; 56(6):e99-101.

29. Littleton SW, Mokhlesi B. The pickwickian syndromeobesity hypoventilation syndrome. Clin Chest Med. 2009; 30(3):467-78.

30. Mokhlesi B. Obesity hypoventilation syndrome: a stateof-the-art review. Respir Care. 2010; 55(10):1347-62.

31. Carroll L. Alice's Adventures in Wonderland. London: Chadwick and Sons; 1865.

32. Farooq O, Fine EJ. Alice in Wonderland Syndrome: A Historical and Medical Review. Pediatr Neurol. 2017; 77:511.

33. Podoll K, Ebel H, Robinson D, Nicola U. Sintomi essenziali ed accessori nella sindrome di Alice nel paese delle meraviglie. Minerva Med. 2002; 93(4):287-94.

34. Liu AM, Liu JG, Liu GW, Liu GT. "Alice in wonderland" syndrome: presenting and follow-up characteristics. Pediatr Neurol. 2014; 51(3):317-20.

35. Todd J. The syndrome of Alice in Wonderland. Can Med Assoc J. 1955; 73(9):701-4.

36. Lippman CW. Certain hallucinations peculiar to migraine. J Nerv Ment Dis. 1952; 116(4):346-51.

37. Zwijnenburg PJ, Wennink JM, Laman DM, Linssen WH. Alice in Wonderland syndrome: a clinical presentation of frontal lobe epilepsy. Neuropediatrics. 2002; 33(1):53-5.

38. Häusler M, Ramaekers VT, Doenges M, Schweizer K, et al. Neurological complications of acute and persistent Epstein-Barr virus infection in paediatric patients. J Med Virol. 2002; 68(2):253-63.

39. Bernal Vañó E, López Andrés N. Un caso de síndrome de Alicia en el país de las maravillas en probable relación con el uso de montelukast. An Pediatr (Barc). 2013; 78(2):127-8.

40. Zaidi S, Gandhi J, Vatsia S, Smith NL, et al. Congenital central hypoventilation syndrome: An overview of etiopathogenesis, associated pathologies, clinical presentation, and management. Auton Neurosci. 2018;210:19.

41. Mellins RB, Balfour HHJr, Turino GM, Winters RW. Failure of automatic control of ventilation (Ondine's curse). Report of an infant born with this syndrome and review of the literature. Medicine (Baltimore). 1970; 49(6):487-504.

42. Severinghaus JW, Mitchell RA. Ondine's curse - Failure of respiratory center automaticity while awake. Clin Res. 1962; 10:122.

43. Navarro FA. Dos personajes literarios en el lenguaje de la neurología: Ondine (II). Rev Neurol. 1997; 25(146):1629-35.

44. Wyman AL. The curse that never was. Lancet. 1980; 315(8177):1094.

45. Tamarin FM, Goldberg RJ, Brandstetter RD. The tale of Ondine: a curse, a kiss, a clasp, and a comment. N Y State 
194 / Arch Argent Pediatr 2019;117(3):188-194 / Special article

J Med. 1989; 89(4):196-8.

46. Goic A. Sobre el uso de epónimos en medicina. Rev Med Chile. 2009; 137(11):1508-10.

47. Woywodt A, Matteson E. Should eponyms be abandoned? Yes. BMJ. 2007; 335(7617):424.

48. Alcaraz Ariza MA. Los epónimos en medicina. Ibérica.
2002; 4:55-73.

49. Musso CG, Enz PA. El arte como instrumento educativo en medicina. Arch Argent Pediatr. 2014; 112(6):494-5.

50. Musso CG, Enz PA, Werbin E. El símbolo y su función terapéutica: en busca de sus fundamentos científicos. Arch Argent Pediatr. 2016; 114(5):403-4. 